\title{
Protection of Human \\ Research Subjects
}

\author{
A Practical Guide to
}

Federal Laws and Regulations 


\title{
Protection of Human
}

\section{Research Subjects}

\author{
A Practical Guide to \\ Federal Laws and Regulations
}

\section{Dennis M. Maloney}

Boys Town USA Program

Boys Town, Nebraska

With a chapter by James H. Sweetland

Foreword by Kenneth J. Ryan

Plenum Press - New York and London 
Library of Congress Cataloging in Publication Data

Maloney, Dennis M.

Protection of human research subjects.

Bibliography; p.

Includes index.

1. Human experimentation in medicine - Law and legislation - United States. I. Title. [DNLM: 1. Human experimentation-United States-Legislation. 2. ResearchUnited States-Legislation. W 20.5 M257p]

KF3827.M38M34 1984

344.73'0419

$84-4873$

ISBN-13: 978-1-4612-9679-9

e-ISBN-13: 978-1-4613-2703-5

DOI: $10.1007 / 978-1-4613-2703-5$

This publication is designed to provide accurate and authoritative information in regard to the subject matter covered. It is offered with the understanding that the publisher and author are not engaged

in rendering legal, accounting, or other professional services. If legal advice or other expert assistance is required, the services of a competent professional person should be sought.

(C) 1984 Plenum Press, New York

Softcover reprint of the hardcover 1st edition 1984

A Division of Plenum Publishing Corporation 233 Spring Street, New York, N.Y. 10013

All rights reserved

No part of this book may be reproduced, stored in a retrieval system, or transmitted, in any form or by any means, electronic, mechanical, photocopying, microfilming, recording, or otherwise, without written permission from the Publisher 
For my parents,

Bernard and Margaret Maloney,

who taught me very early to respect the rights of others 


\section{Foreword}

Regulations on human subjects research have evolved over a 20 -year period and now provide a formal set of requirements for the conduct of federally sponsored studies. Over time, government regulations, like taboos in primitive societies, develop a life of their own, seemingly dissociated from their origins and justifications. When the investigator suffers the burdens of trying to comply with complex rules, it is easy for him or her to lapse into a frustration that can be eased by being informed or reminded of why the rules were created in the first place and what they were designed to accomplish. Dennis Maloney's work provides a handy historical record of the processes by which the regulations were created and modified. He also recounts his own experience with research at Boys Town and provides instructions on how to cope with the system. It is difficult to find in one place the current status and appropriate citations for regulations as well as the contacts and know-how to obtain more information on the subject. In this respect, by providing a history and guide to interpretation and compliance, "Protection of Human Subjects" is a reference of importance and utility to the investigator entering into or working in the field of biomedical or behavioral research involving human subjects. Of no less importance, is the fact that the creation and modification of regulations is a continuous process, and investigators as well as an informed public should be prepared to participate in the development of sensible rules that serve the needs of subjects, science, and society.

Kenneth J. Ryan, M.D.

Chairman, 1974-1978 National Commission for the Protection of Human Subjects of Biomedical and Behavioral Research 


\section{Acknowledgments}

From 1974 to 1982 there have been numerous individuals who have contributed to my interest in this field and supported my work in a variety of ways. Initially, I must thank Larry Larson, Ph.D., who provided assistance through his role as chairman of the Institutional Review Board at Western Carolina Center, Morganton, North Carolina. Certainly, Saleem Shah, Ph.D., Jim Breiling, Ph.D., and Tom Lalley, M.A. (Center for Studies of Crime and Delinquency at the National Institute of Mental Health, Washington, D.C.) guided my early efforts in working with human research subjects and suggested additional source materials in this area.

I gratefully acknowledge the cooperation and untiring efforts of members of the Institutional Review Board at Father Flanagan's Boys' Home (Boys Town): John Barksdale, M.A., Cary Bell, Ph.D., Vaughn Call, Ph.D., David Coughlin, Ph.D., Dennis Culver, M.A., David Cyr, Ph.D., James Garbarino, Ph.D., Kay Graham, Shelton Hendricks, Ph.D., Betty Johnson, the Rev. James Kelly, Richard Lippmann, Ph.D., Luther Otto, Ph.D., James Peck, Ph.D., and Bill Thornton, M.A. As a member of this committee for two years, and then as its chairman, I became more aware of the complexities of the field and the often thankless task of professionals asked to review the work of others with a scarcity of clear guidelines available as support. I offer my congratulations to the committee members, their successors, and our colleagues around the country who struggle to keep abreast of a rapidly changing aspect of research and human services.

I would also like to thank the members of the Legal Issues Committee and the Legislative Committee of the National Teaching-Family Association: Hewitt ("Rusty") Clark, Ph.D., Pam Daly, Ph.D., Jack Freeman, M.A., Paul Gilford, Ph.D., Robert Jones, Ph.D., Kathryn Kirigin Ramp, Ph.D., Michael McManmon, M.A., Michael Pyykola, and Ron Sexton, Ph.D. As chairman of these committees from 1975 to 1979 , I benefitted from the counsel and advice of these representatives of research and service organizations from across the country. 


\section{Contents}

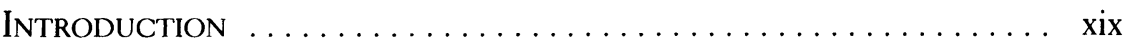

\section{PART I: GUIDELINES FOR RESEARCH}

Chapter 1. Federal Commissions and Advisory Boards $\ldots . . .3$

The National Commission for the Protection of Human Subjects of Biomedical and Behavioral Research ............... 4

The National Research Act $\ldots \ldots \ldots \ldots \ldots \ldots \ldots \ldots \ldots . \ldots 6$

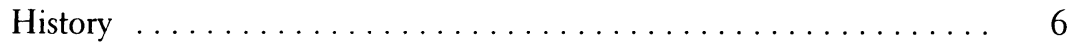

Purpose .............................. 7

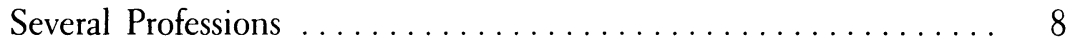

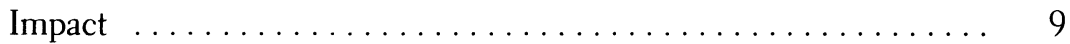

Commission Procedures $\ldots \ldots \ldots \ldots \ldots \ldots \ldots \ldots \ldots \ldots, 10$

Commission Meetings $\ldots \ldots \ldots \ldots \ldots \ldots \ldots \ldots \ldots \ldots \ldots \ldots$

Commission Reports ........................... 13

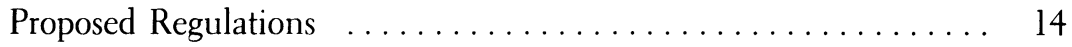

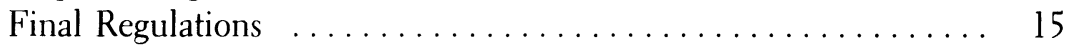

The President's Commission for the Study of Ethical Problems in

Medicine and Biomedical and Behavioral Research ........... 15

The Ethics Advisory Board ........................ 18

Who Does What? ............................. 20

The Belmont Report .......................... 20

Summary ............................... 21

APPENDix 1.1. The National Research Act .................. 23 
ApPENDIX 1.2. The Belmont Report $\ldots \ldots \ldots \ldots \ldots \ldots \ldots \ldots \ldots, 31$

APPENDIX 1.3. The President's Commission for the Study of Ethical

Problems in Medicine and Biomedical and Behavioral Research

Chapter 2. Institutional Review Boards $\ldots \ldots \ldots \ldots \ldots \ldots . \ldots 7$

History of IRB Development $\ldots \ldots \ldots \ldots \ldots \ldots \ldots \ldots \ldots, 48$

Dual Function for IRBs $\ldots \ldots \ldots \ldots \ldots \ldots \ldots \ldots \ldots \ldots \ldots$

Major Changes for IRBs $\ldots \ldots \ldots \ldots \ldots \ldots \ldots \ldots \ldots \ldots \ldots$

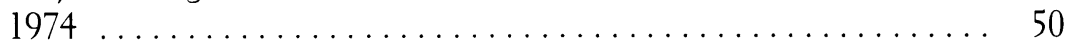

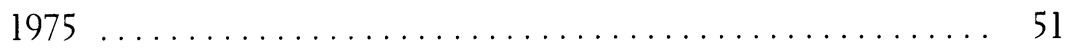

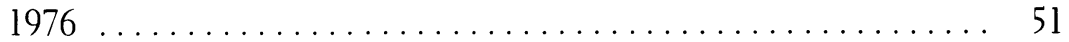

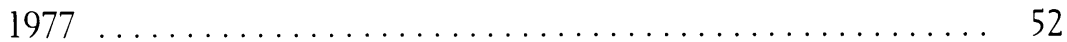

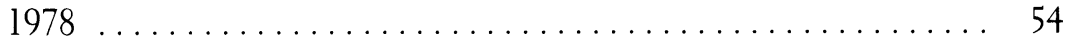

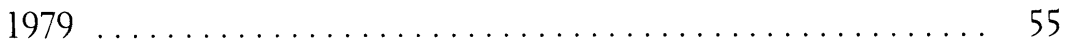

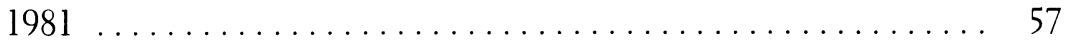

Health and Human Services and the Food and Drug

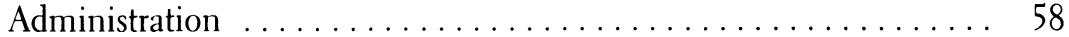

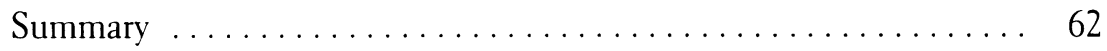

APPENDix 2.1. Regulations by the Department of Health and

Human Services (HHS) for Institutional Review Boards and

Informed Consent ............................. 65

APPENDIX 2.2. Regulations by HHS for "Expedited Review" ........ 79

APPENDIX 2.3. Regulations by the Food and Drug Administration

(FDA) for Operation of Institutional Review Boards ........... 81

APPENDIX 2.4. Regulations by FDA for "Expedited Review" ......... 95

APPENDIX 2.5. A Comparison of HHS and FDA Rules Governing

Operation of Institutional Review Boards ................. 97

APPENDIX 2.6. A Comparison of HHS and FDA Rules Governing

Operation of Institutional Review Boards for "Expedited Reviews" . . 111

Chapter 3. Informed Consent $\ldots \ldots \ldots \ldots \ldots \ldots \ldots \ldots \ldots \ldots$

History of Informed Consent $\ldots \ldots \ldots \ldots \ldots \ldots \ldots \ldots \ldots \ldots \ldots$

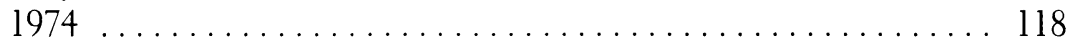

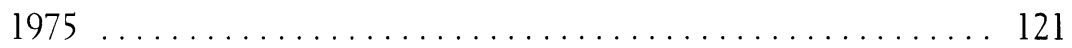

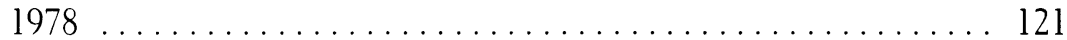

Informed Consent Today $\ldots \ldots \ldots \ldots \ldots \ldots \ldots \ldots \ldots \ldots \ldots \ldots$

Elements of Consent .......................... 124 
Who Must Sign the Informed Consent Form . . . . . . . . . 127

Two Types of Written Consent ................... 130

Example of an Informed Consent Form $\ldots \ldots \ldots \ldots \ldots \ldots \ldots \ldots$

The "Looking at Life" Study ....................... 132

Was Written Consent Necessary? ...................... 135

Correct Consent Elements in Example ................. 139

Consent Rules for the Food and Drug Administration .......... 140

Informed Consent for Treatment ....................... 141

A Contract for Consent ........................ 141

The National Teaching-Family Association $\ldots \ldots \ldots \ldots \ldots . . \ldots 142$

Some Problems Associated with Informed Consent ........... 144

Researcher Resistance ............................. 144

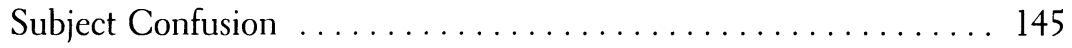

Summary ................................ 147

ApPENDIX 3.1. Regulations by the Department of Health and

Human Services for Informed Consent ... . . . . . . . . . . . . . . . . 149

APPENDIX 3.2. Regulations by the Food and Drug Administration for

Informed Consent .............................. 155

ApPENDIX 3.3. A Comparison of HHS and FDA Rules Governing

Informed Consent

Chapter 4. How to Get Research Approved by an

Institutional Review BoARd ..................... 171

Establishing an Institutional Review Board .............. 172

Obtaining Federal Approval of an IRB ............... 172

Correspondence with Federal Agency in Washington ........ 177

Institutional Review Boards Around the United States . . . . . . . 190

Special Assurance and General Assurance . . . . . . . . . . . . . . . . 190

Special Assurance .............................. 191

General Assurance ................................ 191

Applying to an IRB for Approval $\ldots \ldots \ldots \ldots \ldots \ldots \ldots \ldots \ldots . \ldots \ldots$

Memo Describing IRB Review Steps .................. 193

Detailed Instructions for Preparing IRB Proposal . . . . . . . . . 195

IRB Roster ................................. 202

Schedule of IRB Meetings $\ldots \ldots \ldots \ldots \ldots \ldots \ldots \ldots \ldots \ldots 20 \ldots \ldots$

Sample Forms ............................ 203

The Researcher and the IRB: A Complicated Relationship ....... 219

A National IRB Survey .......................... 220

IRB Survey Design $\ldots \ldots \ldots \ldots \ldots \ldots \ldots \ldots \ldots \ldots \ldots . \ldots 220$ 


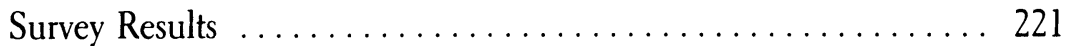

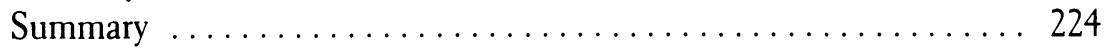

APPENDIX 4.1. 61st Cumulative List of Institutions Which Have

Established General Assurances of Compliance with HEW

(now HHS) Regulations on Protection of Human Subjects

APPENDIX 4.2. Regulations by the Department of Health and

Human Services on General Assurance ................... 25

Chapter 5. Freedom of Information and Privacy $\ldots \ldots \ldots \ldots 255$

Government Files Only . . . . ................ 256

The Freedom of Information Act (FOIA) $\ldots \ldots \ldots \ldots \ldots \ldots \ldots 256$

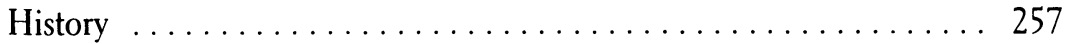

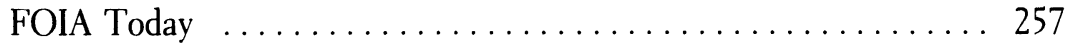

The FOIA and The Privacy Act ................... 260

The Privacy Act ............................. 261

The Privacy Act Today ......................... 261

Basic Elements of the Privacy Act $\ldots \ldots \ldots \ldots \ldots \ldots \ldots 262$

The Sunshine Act ........................... 263

Basic Elements of the Sunshine Act $\ldots \ldots \ldots \ldots \ldots \ldots . \ldots 263$

Sunshine Act and the Researcher .................... 264

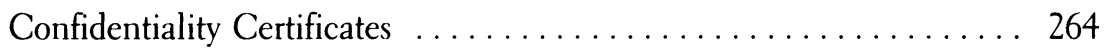

Research on Sensitive Issues ........................ 264

Confidentiality Certificates in Health and Human Services ...... 265

Impact of Privacy Rules on Research ................... 266

Impact on Federal Agencies ......................... 267

Impact on Researchers ........................... 268

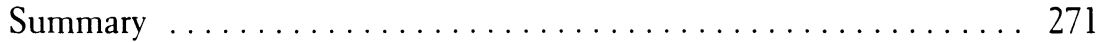

APPENDIx 5.1. The Freedom of Information Act ............ 273

APPENDIX 5.2. The Privacy Act of 1974 ................... 279

APPENDIX 5.3. Government in the Sunshine Act ............. 295

APPENDIX 5.4. Protection of Identity of Research Subjects .......... 303

\section{PART II: RESEARCH WITH SPECIAL POPULATIONS}

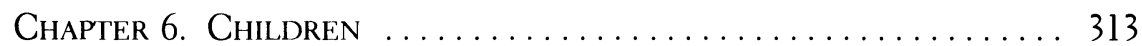

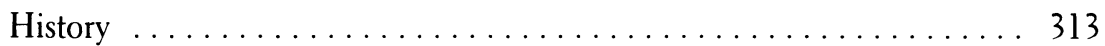

1978 Rules ................................. 314 
1983 Rules ..................................... 314

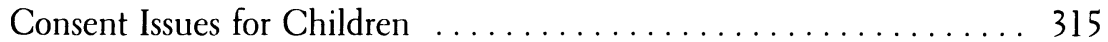

Assent versus Consent versus Permission .............. 315

Children as Wards of the State ...................... 318

Extra Responsibilities for an IRB . ................. 318

Research with Children and Minimal Risk ............... 319

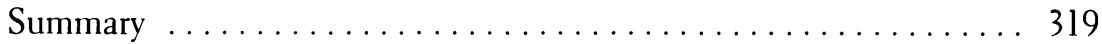

APPENDIX 6.1. Protection of Human Subjects in Research Involving

Children ..................................... 321

Chapter 7. Students $\ldots \ldots \ldots \ldots \ldots \ldots \ldots \ldots \ldots \ldots \ldots \ldots \ldots \ldots \ldots$

History .................................... 328

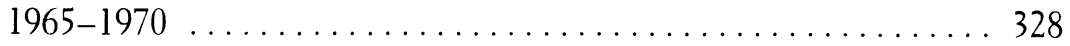

Privacy and Student Records ......................... 329

1974: An Active Year . . . . . . . . . . . . . . . . . . . . . . . . . 329

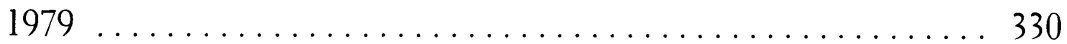

The Buckley Amendment .......................... 330

After the Buckley Amendment ........................ 331

Opposing Sides on Student Privacy $\ldots \ldots \ldots \ldots \ldots \ldots \ldots \ldots \ldots \ldots \ldots \ldots$

Parents versus Students ........................... 333

Educational Research ........................... 333

Politics and Education Rules ......................... 335

Summary .................................. 336

APPENDIX 7.1. Protection of Human Subjects in Research Involving

Students ..................................... 337

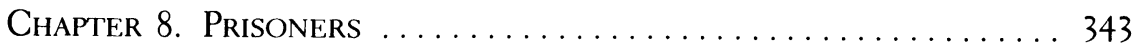

Health and Human Services ......................... 344

Negative Findings .......................... 344

Broad Scope of Restrictions . . .................... 345

Current Rules .................................. 346

IRBs and Prisoner Research .................... 346

Food and Drug Administration ...................... 347

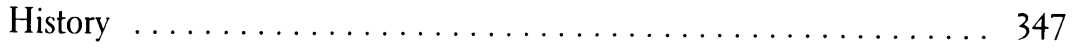

Current Rules ................................... 348

Summary ................................ 349

APPENDIX 8.1. Regulations by the Department of Health and

Human Services for Protection of Prisoners as Research Subjects ... . 351 
ApPendix 8.2. Proposed Regulations by the Food and Drug

Administration for Protection of Prisoners as Research Subjects

Chapter 9. Fetuses, Pregnant Women, and In Vitro

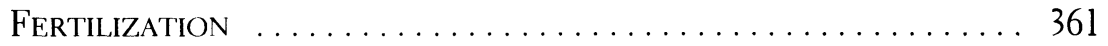

Fetuses .................................... 361

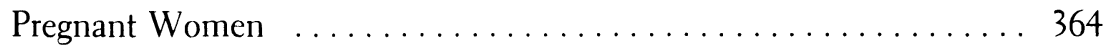

In Vitro Fertilization .......................... 365

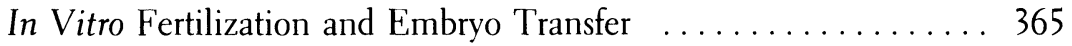

Legal Complications ......................... 366

Regulatory History ............................ 367

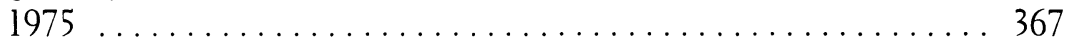

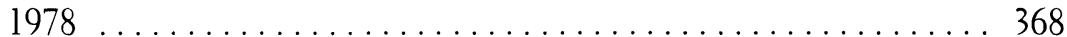

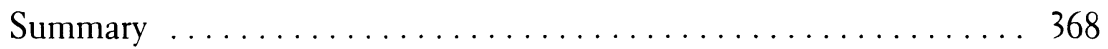

APPENDix 9.1. Regulations of the Department of Health and Human

Services for Research with Fetuses, Pregnant Women, and In Vitro

Fertilization ... . . . . . . . . . . . . . . . . . . . . . . . . . . . 371

Chapter 10. Persons Institutionalized as Mentally

DisAbled ................................... 377

Regulatory History . . . . . . . . . . . . . . . . . . . . . . 377

Definition of Mentally Infirm . . . . . . . . . . . . . . . . . 378

Community-based Settings ............................ 379

Consent Conditions ............................. 380

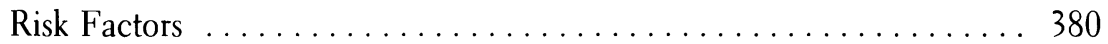

Summary ................................. 381

APPEndix 10.1. Proposed Regulations by the Department of Health

and Human Services for Research Involving Persons

Institutionalized as Mentally Disabled

\section{PART III: KEEPING UP WITH CHANGING RULES}

Chapter 11. How to Be Informed and Involved $\ldots \ldots \ldots \ldots 393$ James Sweetland

How a Bill Becomes a Law ......................... 393

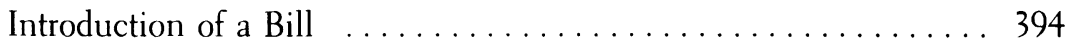




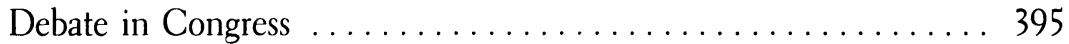

Presidential Action ............................ 396

The Bill Becomes Law .......................... 396

How a Regulation Becomes a Regulation ................. 397

The Federal Register .............................. 398

Code of Federal Regulations . . . . . . . . . . . . . . . . . . 398

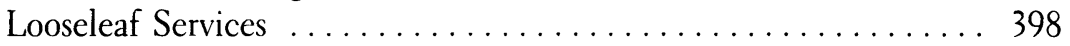

How Laws and Regulations Are Cited .................. 399

Finding Federal Laws ........................... 400

Finding Federal Regulations . . . . . . . . . . . . . . . . . 403

Keeping Current .............................. 404

Congressional Record ................................ 404

Calendars .................................. 404

Federal Register ................................ 404

Commercial Services ............................. 405

Retrieving Documents .......................... 408

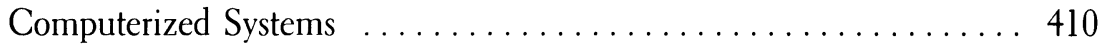

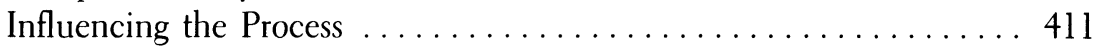

State Laws and Regulations $\ldots \ldots \ldots \ldots \ldots \ldots \ldots \ldots \ldots \ldots$

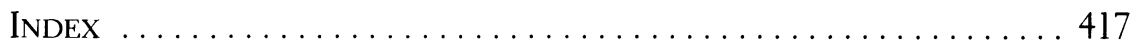




\section{Introduction}

If you conduct any kind of research with humans or provide treatment to other persons you should already be familiar with much of the material of this book. But it is much more likely that the information will be new. Why is this so, in this age of mass media and rapid communications? There are several reasons why you may lack such vital information, despite the possibility of lawsuits against unwary professionals who may unwittingly abridge the rights of subjects. Lawsuits have already occurred in the area of treatment, where professionals have violated client rights. Perhaps the most salient of the reasons is the sheer bulk of the communications. As a primary example of information overkill, the federal government in recent years has spawned an enormous complex of bureaucratic regulatory offices. This has not only left the human services professional bewildered by a massive array of rules but it has also had an observable effect on our national economy.

An Associated Press news release on January 12, 1980, ${ }^{1}$ revealed that this regulatory function directly contributes to inflation in the United States. In fact, the news release noted that the federal government has 90 regulatory offices issuing around 7,000 rules a year! Further, economists estimated that the financial burden of these regulations borne by Americans was a trifling $\$ 50$ billion to $\$ 150$ billion a year. Obviously, only a small fraction of these regulations pertain to protection of subjects and clients, but it is little wonder that most health care and human service professionals cannot keep up with new laws and regulations.

This concern must be tempered with attention to the numerous advantages provided by regulations designed to protect American citizens. Indeed, a backlash against regulatory agencies is not only unwarranted but also can hurt consumers in the long run. ${ }^{2}$ In the area of human services, however, the regulations 
often deal with philosophical or moral issues rather than safety standards or advertising guidelines. The increase in regulations in human services has paralleled the increasing political visibility of human rights as a separate issue, particularly in the United States.

Although the concept of human rights is not new to twentieth-century America, the role of the federal government in this field definitely is new. By the late 1970s, there had grown a befuddling maze of regulations and legislation originally designed to govern only research with human subjects. As one example, most professionals have heard of "informed consent" in this regard, but the construction of such an agreement can be a tedious and frustrating task for the most conscientious researcher.

Mistakenly, some researchers still consider informed consent as the primary aspect of the researcher-subject relationship. It is not. It is merely the most visible aspect related to protection of human rights. Other issues such as confidentiality of research information are also involved. Furthermore, there are additional considerations which researchers must keep in mind when working with particular types of subjects (e.g., with children).

But what about those of you who are not engaged in research but do provide treatment for clients? What has all this to do with you? The answer is simple: it has a great deal to do with you. Historically, much of the material included in this book grew out of regulations or legislation regarding human research subjects. As we shall discover, however, many guidelines have since moved into the area of treatment and are dealt with in several chapters of this book. For example, educational researchers may be familiar with the widely publicized Buckley Amendments (although they may be using the wrong version as their guideline), but how many educators are familiar with provisions of that body of regulations that affect access to student records, whether research is intended or not? Does the psychiatrist or psychologist have a right to view education records as part of treatment planning for a student receiving counseling? And what about your records-who has the right to see them?

This reference book is constructed in such a fashion that you should be able to answer most such questions. For example, a psychiatrist working with mentally retarded clients might examine Chapter 10 closely ("Persons Institutionalized as Mentally Disabled"), whereas the school counselor may wish to concentrate on Chapter 7 ("Students"). In general, however, it is recommended that you peruse all of Part 1 , Chapters $1-5$, to understand the general framework of legislation and regulations affecting both research and practice. Part 2, Chapters $6-10$, can then best be used as a source of additional material for working with specific populations of subjects or clients.

Even if you only use this book as an occasional reference source, it is strongly urged that you read Chapter 11 ("How to Be Informed and Involved") by James Sweetland, M.L.S., Ph.D. And read all of it? Why? Because of the very 
problem mentioned initially, that of professionals who are unaware of the tremendous amount of legal precedent being set that can so significantly affect their careers. Further, many of these rules come into existence with unbelievably trivial amounts of input from the very professions most likely to be affected by them. This phenomenon can be altered only by professionals who know what to do and when to do it.

For those of you intending to use this entire book as a textbook, an effort has been made to relate material in one chapter to issues presented in another. Where possible, a chronological order of developments has been discussed within the separate topic areas. In particular, Part 1 is presented largely in this fashion, with Chapter 1 containing a brief synopsis of the recent developments in the field, starting with the achievements of the highly influential National Commission for the Protection of Human Subjects of Biomedical and Behavioral Research.

A word of caution: Do not rely on this text as your legal defense in matters of possible litigation. Always seek legal counsel in such situations. This reference work does not contain everything there is to know about the rights of human research subjects and treatment clients. Indeed, it seldom delves into the ethical or moral issues that underlie the guidelines and practical recommendations. Readers interested in the more philosophical aspects of these issues will find examples of such texts listed in various footnotes. In addition, it should be noted that the focus of this work is on federal rules. Readers interested in local applications are urged to contact their state's professional societies or state bar association.

As a reference work, this book should serve your purposes for most topics most of the time. It was written for the use of the author as well as for others, since the author has found it almost impossible to keep track of federal legislation and regulations from the many sources that publish different updates. The author was dismayed also by the increasing bulges in crowded files and decided that one book would be more useful-and would take up less room in his office. Readers who can suggest modifications of this work will find their comments and feedback much appreciated.

Finally, readers should take note of the fact that rules can change rapidly in this area; therefore quoted rules or laws may have changed by the time this volume is published. Nevertheless, the regulatory and legislative history of protection of human rescarch subjects clearly shows that new rules are based on old ones. Thus the quoted texts in this work should serve as reliable guides for the foreseeable future. In addition to the numerous methods listed throughout this book for keeping up to date with relevant rules, readers can telephone the National Institute of Health's Office for Protection from Research Risks (301-496-7005) or the Associate Commission for Health Affairs at the Food and Drug Administration (301-443-6143) for immediate help. 